\title{
Standardization of Process for Custard Apple Milk Shake
}

\author{
P. H.Bakane* ${ }^{1}$, M.M.Khakare ${ }^{2}$, M.H.Gajabe ${ }^{3}$, M.B.Khedkar ${ }^{4}$ \\ ${ }^{1}$ Associate Professor, Department of Agricultural Process Engineering, Dr. PDKV, Akola (M.S.), India \\ ${ }^{2}$ Project Assistant, Department of Agricultural Process Engineering, Dr. PDKV, Akola (M.S.), India \\ ${ }^{3}$ Junior Research Fellow, Department of Agricultural Process Engineering, Dr. PDKV, Akola (M.S.), India \\ ${ }^{4}$ Junior ResearchAssistant,ARCRP On Seed Tech. Research Unit,Dr. PDKV, Akola(M.S.), India
}

\begin{abstract}
The present investigation was undertaken to optimize the proportion of custard apple pulp and milk in the custard apple milk shake and to evaluate physicochemical, microbiological and sensory attributes of prepared custard apple milk shake.Fully ripened custard apple fruit of Balanagar variety was obtained from farmer's field and used for preparation of milk shake. The pulp of custard apple fruits was extracted by PDKV de-seeding machine. The pulp separated by machine were packed in LDPE bags with 0.1 percent Potassium metabisulphide $(K M S)$ and stored in deep freeze at $-20^{\circ} \mathrm{C}$ temperatures. This stored pulp was used for preparation of milk shake. Custard apple milk shake was prepared from different proportion of milk and custard apple pulp i.e., 100:0, 90:10, 80:20 ,75:25, 70:30, 65:35, 60:40. Colour, pH, titrable acidity, TSS, water activity, total sugar, viscosity and microbial load of prepared custard apple milk shake were determined by following standard methods. The sensory evaluation of custard apple milk was carried out by 9 point Hedonic scale.The TSS of custard apple milk shake was found to be increased from 17.4 to $24.20^{\circ}$ Brix with increase in custard apple pulp from 0 to $40 \%$ in the milk shake. Similarly acidity, total sugar and viscosity were also found to be increased with increase in percentage of custard apple pulp. Whereas $p H$ of custard apple milk shake was found to be decreased with increase in percentage of custard apple pulp in prepared milk shake. Bacterial load of custard apple milk shake was found to be in the range of $1.5 \times 10^{3}$ to $11.5 \times 10^{3} \mathrm{cfu} / \mathrm{g}$. The fungal count in the sample was in the ranged of $1.5 \times 10^{3}$ to $8.0 x$ $10^{3} \mathrm{cfu} / \mathrm{g}$. The study concluded that blending of custard apple pulp (35\%) with cow milk (65\%) resulted in most acceptable milk shake and rank between like very much to like extremely.
\end{abstract}

Keywords-Custard apple pulp, Composition, Cow milk, Milk shake, sensory evaluation.

\section{INTRODUCTION}

Milk shake, a cold beverage, prepared from milk and ice cream, is a palatable and perfect health-diet due to its low fat and sugar contents, and high milk solids-not-fat (MSNF) content than ice cream (Sharma and Gupta,1978). It can be made more delicious and nutritious with addition of fruits. Fruits are excellent source of phytochemicals which are essential for human health and relished by consumers in all season. Custard Apple (AnonaSquamosaL.) is one such fruit.

Custard Apple (AnonaSquamosaL) is a well-known fruit for its nutritional composition as well as for its medicinal properties. This fruit is commonly known as custard apple, sugar apple, sweet soup, sour soup. Custard Apple is a popular fruit of the tropical states of India, with a very short season, lasting for about 3 months a year.

The pulp may be consumed raw or transformed into various food products. The taste of pulp is aromatic sweet, with custard like flavor. It has great potential for value addition through processing (Kotechaet al.,2000).In India custard apple is widely grown fruit crop in Maharashtra, Madhya Pradesh, Chhattisgarh, Andhra Pradesh, Rajasthan and Karnataka. In the month of October- December there is glutin the market.

The custard apple is mostly used as a dessert fruit for its delicious taste and nutritive values. The pulp is used in preparation of ice-cream and beverages (Chikhalikaret $a l ., 2000)$.The custard apple pulp is easy to digest and it can be consumed easily by children and people of all ages (Kirtikar and Basu1955). Custard apple fruit is excellent source of carbohydrates (23.5\%), minerals $(0.9 \%)$, and protein (1.6\%) (Gopalanet al.,1991). A total soluble solid in the pulp is $22.3^{\circ}$ Brix. It is also a good source of vitamin A and $\mathrm{C}$ is known to serve as blood tonic (Rao,1974). The pulp has a pleasant texture and flavor. It is sweet with moderate acidity (Sravanthiet al., 2014). 
In India area and production of custard apple was $21.77,000$ ha and165.15,000 MT, respectively in 2013-14 (Indian Horticulture Database, 2014.http://nhb.gov.in).Average percent of pulp, peel and seeds of custard apple fruits were $40.38 \%, 48.62 \%$, and $10.30 \%$, respectively (Bakaneet al., 2015)

Milk shake sold by fruit juice centers in many parts of India during whole year (Sharma and Gupta,1978). Blending milk with different fruits to formulated tasty and palatable products is gaining importance. Therefore, the aim of this study was to optimize the proportion of custard apple pulp and milk in the custard apple milk shake and to evaluate the physicochemical and sensory attributes of prepared custard apple milk shake.

\section{MATERIAL AND METHOD}

Fully ripened custard apple fruit of Balanagar variety was obtained from farmer's field and used for preparation of milk shake. The pulp of custard apple fruits was extracted by PDKV de-seeding machine (Bakaneet al., 2015) The pulp separated by machine were packed in LDPE bags with 0.1 percent Potassium metabisulphide (KMS) and stored in deep freeze at $-20^{\circ} \mathrm{C}$ temperatures (Bakaneet al., 2015)This stored pulp was used for preparation of milk shake. Cow milk required for study was obtained from local market of Akola (Maharashtra).

Treatments details:

For optimization of proportion of custard apple pulp and milk following blends of pulp and milk was studied.

$\mathrm{T} 0=100 \%$ cow milk by weight (Control)

$\mathrm{T} 1=90 \%$ cow milk and $10 \%$ custard apple pulp by weight, $\mathrm{T} 2=80 \%$ cow milk and $20 \%$ custard apple pulp by weight, $\mathrm{T} 3=75 \%$ cow milk and $25 \%$ custard apple pulp by weight, T4 $=70 \%$ cow milk and $30 \%$ custard apple pulp by weight, T5 $=65 \%$ cow milk and $35 \%$ custard apple pulp by weight, T6 $=60 \%$ cow milk and $40 \%$ custard apple pulp by weight.

Preparation of custard apple milk shake:

Custard apple milk shake was prepared as per the method (Sharma and Gupta,1978) with slight modification. The flow chart of preparation of Custard apple shake is shown in Fig 1.

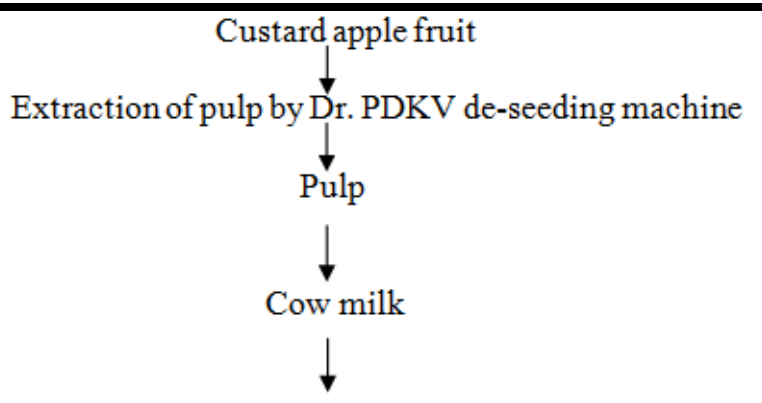

Add Custard apple Pulp

(@) 10\%,20\%,25\%,25\%,30\%,35\% and 40\%)

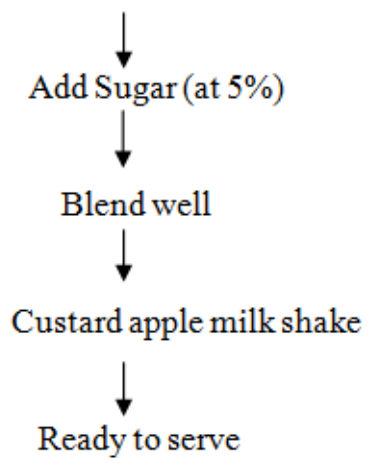

Fig.1: Flow charts for preparation of Custard apple shake

Chemical characteristics of custard apple milk shake: Analysis of custard apple milk shake

Custard apple milk shake was analyzed for acidity, $\mathrm{pH}$, Total soluble solid (TSS), Water activity and Total sugar. Total soluble solid (TSS) was measured by using Erma Hand Refractometer. Titrable acidity was determined by titration method (Ranganna, 1986) while total sugar of custard apple milk shake was measured by Anthron method (Thimmaiah,1999). Water activity was determined by Aqua lab water activity meter and colour of pulp in terms of Lvalue was determined by Konica Minolta Chromameter (CR-400).

\section{Microbiological Evaluation of the Product}

For microbial analysis, $1 \mathrm{gm}$ of sample was serially diluted to $10^{-2}$ dilution and the aliquots of all the dilutions $\left(10^{-0}, 10^{-1}\right.$ and $10^{-2}$ ) were plates on nutrient agar for total bacterial count and on potato dextrose agar for fungus. The experiment was carried out in triplicates for each sample. All plates were incubated at $37^{\circ} \mathrm{C}$ for 24 hours.

\section{Sensory Evaluation:}

The sensory characteristics, viz., colour and appearance, flavor, consistency, mouthfeel and overall acceptability were evaluated by panel 10 members. The judgment were made to rating product on a using "9-point Hedonic scale" developed by Quarter Master, Food and Container Institute, USA (Gupta, 1976) with corresponding descriptive terms 
ranging from 9 'like extremely' to 1 'dislike extremely'.The scores were pooled and mean score for overall acceptability was worked out.

Statistical analysis:
The results obtained during the course of investigation were subjected to statistical analysis by using Completely Randomized Design (Panse andSukhatme,1976).

\section{RESULTS AND DISCUSSION}

Chemical characters of custard apple milk shake

Table.1: Physicochemical properties of custard apple milk shake

\begin{tabular}{|c|c|c|c|c|c|c|c|c|c|}
\hline \multirow[t]{2}{*}{ Treatments } & \multirow{2}{*}{$\begin{array}{l}\text { TSS } \\
\left({ }^{\circ} \text { Brix }\right)\end{array}$} & \multirow[t]{2}{*}{$\mathrm{pH}$} & \multirow{2}{*}{$\begin{array}{l}\text { Acidity } \\
(\%)\end{array}$} & \multirow{2}{*}{$\begin{array}{l}\text { Water } \\
\text { activity }\end{array}$} & \multirow{2}{*}{$\begin{array}{l}\text { Colour } \\
\text { (L-value) }\end{array}$} & \multirow{2}{*}{$\begin{array}{l}\text { Total } \\
\text { sugar } \\
(\%)\end{array}$} & \multirow{2}{*}{$\begin{array}{l}\text { Viscosity } \\
\text { (Cp) }\end{array}$} & \multicolumn{2}{|c|}{ Microbial load (cfu/g) } \\
\hline & & & & & & & & N.A. & PDA \\
\hline T0 & $17.4^{\mathrm{e}}$ & $6.62^{a}$ & 0.13 & 0.979 & 90.07 & $16.24^{\mathrm{d}}$ & $124.6^{\mathrm{g}}$ & $1.5 \times 10^{3 \mathrm{e}}$ & $1.5 \times 10^{3 \mathrm{~d}}$ \\
\hline $\mathrm{T} 1$ & $19.33^{\mathrm{d}}$ & $6.56^{b}$ & 0.13 & 0.965 & 86.52 & $16.89^{c}$ & $153.6^{\mathrm{f}}$ & $4 \times 10^{3 d}$ & $1.5 \times 10^{3 \mathrm{~d}}$ \\
\hline $\mathrm{T} 2$ & $20.80^{c}$ & $6.47^{c}$ & 0.14 & 0.978 & 85.28 & $18.73^{\mathrm{b}}$ & $165.3^{\mathrm{e}}$ & $3.6 \times 10^{3 \mathrm{~d}}$ & $4.6 \times 10^{3 b c}$ \\
\hline $\mathrm{T} 3$ & $22.76^{\mathrm{b}}$ & $6.43^{c}$ & 0.14 & 0.985 & 81.15 & $18.72^{\mathrm{b}}$ & $192^{\mathrm{d}}$ & $5 \times 10^{3 \mathrm{~cd}}$ & $2.5 \times 10^{3 \mathrm{~d}}$ \\
\hline $\mathrm{T} 4$ & $22.10^{\mathrm{b}}$ & $6.45^{c}$ & 0.13 & 0.987 & 83.69 & $18.95^{\mathrm{b}}$ & $372.6^{\mathrm{c}}$ & $11.5 \times 10^{3 a}$ & $3 \times 10^{3 \mathrm{~cd}}$ \\
\hline T5 & $23.90^{\mathrm{a}}$ & $6.35^{d}$ & 0.15 & 0.991 & 83.92 & $19.9^{\mathrm{a}}$ & $407^{\mathrm{b}}$ & $6.6 \times 10^{3 b c}$ & $8 \times 10^{3 a}$ \\
\hline T6 & $24.20^{\mathrm{a}}$ & $6.33^{d}$ & 0.14 & 0.994 & 78.32 & $20^{\mathrm{a}}$ & $418^{a}$ & $7 \times 10^{3 b}$ & $6.5 \times 10^{3 a b}$ \\
\hline 'F Test' & Sig & Sig & NS & NS & NS & Sig & Sig & Sig & Sig \\
\hline $\mathrm{SE}(\mathrm{m} \pm)$ & 0.25 & 0.015 & 0.006 & 0.004 & 1.960 & 0.081 & 0.454 & 0.604 & 0.648 \\
\hline $\mathrm{CD}$ at $1 \%$ & 1.09 & 0.066 & 0.026 & 0.020 & 8.252 & 0.341 & 1.912 & 2.543 & 2.730 \\
\hline
\end{tabular}

Value within a column with the same super scripts are significantly different $(p<0.01)$

\section{Total soluble solid:}

There was gradual increase in TSS of milk shake from 17.4 to $24.2^{\circ}$ Brix with increase in level of custard apple pulp from 0 to $40 \%$. This may be due to that the TSS of custard apple pulp was more than that of milk (Poul,2009).

Colour:

The colour measure in terms of L-value indicates whiteness of product, ranging from 0 (black) to 100 (white.) Data of colour of custard apple milk shake of different treatments are presented in Table 1.The colour value (L- value) of custard apple milk shake was found to be highest in $T_{0}$ treatment than that of other treatments. This may be due to that custard apple milk shake prepared as per the treatment $\mathrm{T}_{0}$ is without custard apple pulp and colour of milk was whiter than the custard apple pulp. The colour value of custard apple milk shake was found to be decreased with increase in proportion of custard apple pulp in the milk shake. The colour of all treatments was found statistically at par.

\section{Water activity:}

The water activity of custard apple milk shake was found to be in the range of 0.965 to 0.994 . There was not found any significant effect of treatments on water activity of custard apple milk shake.

pH:

The $\mathrm{pH}$ of custard apple milk shake was found to be decreased from 6.62 to 6.33 with increase in percentage of custard apple pulp in prepared milk shake. This may be due 
to the $\mathrm{pH}$ of pure milk was more than that of custard apple pulp.

Acidity:

The acidity was found to be increased from 0.12 to $0.14 \%$ with increase in percentage of custard apple pulp in the blend. These finding was supported by the results of (Sharma and Gupta,1978;Kadav, 2001;Kashid, 2005andPoul,2009).

\section{Total sugar:}

There was gradual increase in total sugar with increase in proportion of custard apple pulp in milk shake. This is because pulp contain more sugar than the milk.

Viscosity:

The viscosity indicates flow ability of custard apple milk shake. The viscosity was found to be in the range of 125 to
$418 \mathrm{cp}$. The viscosity was found to be increased with increase in custard apple pulp in the blend. This shows that custard apple milk shake become more viscous with increase in custard apple pulp.

\section{Microbial analysis}

The data present in Table 1 shows the bacterial and fungal load (cfu/g) of custard apple milk shake. Bacterial load of custard apple milk shake was found to be in the range of 1.5 $\mathrm{x} 10^{3}$ to $11.5 \times 10^{3} \mathrm{cfu} / \mathrm{g}$. Total bacterial load was found to increase with increase in $\%$ pulp. Treatment $\mathrm{T} 4$ shows highest bacterial load which is not in trend. This may be due to the experimental error. Fungal load of custard apple milk shake was found to be highest $\left(8 \times 10^{3} \mathrm{cfu} / \mathrm{g}\right)$ in treatment $\mathrm{T} 5$ and lowest $\left(1.5 \times 10^{3} \mathrm{cfu} / \mathrm{g}\right)$ in treatment $\mathrm{T} 0$.

Table.2: Sensory evaluation of custard apple milk shake

\begin{tabular}{|c|c|c|c|c|c|}
\hline Treatment & $\begin{array}{l}\text { Colour and } \\
\text { Appearance }\end{array}$ & Flavor & Consistency & Mouth feel & $\begin{array}{l}\text { Overall } \\
\text { Acceptability }\end{array}$ \\
\hline $\mathrm{T}_{0}$ & $5.87^{\mathrm{f}}$ & $4.18^{\mathrm{f}}$ & $4.78^{\mathrm{f}}$ & $4.43^{\mathrm{g}}$ & $4.08^{\mathrm{e}}$ \\
\hline $\mathrm{T}_{1}$ & $6.18^{\mathrm{d}}$ & $4.81^{\mathrm{e}}$ & $5.45^{\mathrm{e}}$ & $5.39^{\mathrm{f}}$ & $5.84^{\mathrm{d}}$ \\
\hline $\mathrm{T}_{2}$ & $6.24^{\mathrm{d}}$ & $6.02^{\mathrm{d}}$ & $6.18^{\mathrm{d}}$ & $6.18^{\mathrm{e}}$ & $6.20^{\mathrm{c}}$ \\
\hline $\mathrm{T}_{3}$ & $7.03^{c}$ & $6.82^{\mathrm{c}}$ & $6.20^{\mathrm{d}}$ & $7.17^{\mathrm{d}}$ & $6.84^{\mathrm{b}}$ \\
\hline $\mathrm{T}_{4}$ & $7.30^{\mathrm{b}}$ & $7.42^{\mathrm{b}}$ & $7.48^{\mathrm{c}}$ & $7.54^{\mathrm{c}}$ & $7.66^{\mathrm{a}}$ \\
\hline $\mathrm{T}_{5}$ & $7.73^{\mathrm{a}}$ & $8.54^{\mathrm{a}}$ & $7.88^{\mathrm{a}}$ & $8.51^{\mathrm{a}}$ & $7.9^{\mathrm{a}}$ \\
\hline $\mathrm{T}_{6}$ & $6.03^{\mathrm{e}}$ & $7.40^{\mathrm{b}}$ & $7.73^{b}$ & $7.90^{\mathrm{b}}$ & $7.73^{\mathrm{a}}$ \\
\hline 'F Test' & Sig & Sig & Sig & Sig & Sig \\
\hline $\mathrm{SE}(\mathrm{m} \pm)$ & 0.035 & 0.023 & 0.034 & 0.038 & 0.116 \\
\hline $\mathrm{CD}$ at $1 \%$ & 0.149 & 0.098 & 0.145 & 0.163 & 0.490 \\
\hline
\end{tabular}

Value within a column with the same super scripts are significantly different $(\mathrm{p}<0.01)$

\section{Colour and appearance}

The mean score of colour and appearance for different treatment of custard apple milk shake was found in the range of 5.87 to 7.73 . It was observed that increased in level of custard apple pulp in milk shake increases the score of colour and appearance slightly. There was found significant difference between treatments. Treatment $T_{5}$ shows the highest score of colour and appearance.

\section{Flavour}

The data show that $65 \%$ cow milk blended with $35 \%$ custard apple pulp produce rich flavour to milk shake. There was found significant difference of flavour score between the all treatments except treatment $\mathrm{T}_{4}$ and $\mathrm{T}_{0}$ at $1 \%$ level of significance.

\section{Consistency}

www.ijeab.com
The mean score for the consistency attributes of custard apple milk shake was found in the range of 4.78 to 7.88. The treatment $\mathrm{T}_{5}$ scored highest (7.88) among the treatments. The addition of custard apple pulp in the blend, naturally increase the score of consistency. Consistency nothing but the viscosity of custard apple milk shake and viscosity was found to be increased with increase in proportion of custard apple pulp in the blends as given in Table 1. There was found significant difference of consistency score between the all treatment except treatment $\mathrm{T}_{2}$ and $\mathrm{T}_{3}$ at $1 \%$ level of significance (Pkalwad, 2010).

\section{Mouth feel}

The highest mouthfeel score was observed for treatment $\mathrm{T}_{5}$ (8.51) followed by $\mathrm{T}_{6}(7.90), \mathrm{T}_{4}$ (7.54), $\mathrm{T}_{3}(7.17), \mathrm{T}_{2}$ (6.18), $\mathrm{T}_{1}$ (5.39) and lowest for $\mathrm{T}_{0}$ (4.43). It was observed that 
decreasing the per cent of custard apple pulp in the blend was not much accepted by the judges. Custard apple pulp bending of $35 \%\left(\mathrm{~T}_{5}\right)$ was found to be most accepted. The custard apple milk shake prepared with $40 \%$ pulp and $60 \%$ milk was found to be difficult to drink therefore its mouth feel score was less.

\section{Overall Acceptability:}

The mean score of overall acceptability was found to be highest for treatment $T_{5}$ (7.9) followed by $T_{6}$ (7.73), $\mathrm{T}_{4},(7.66), \mathrm{T}_{3}$ (6.84), $\mathrm{T}_{2}(6.20), \mathrm{T}_{1}$ (5.84) and lowest $\mathrm{T}_{0}$ (4.08). The treatment $\mathrm{T}_{5}(35 \%$ custard apple pulp $+65 \%$ milk) was most accepted by the judges than that the other treatment combination.

\section{CONCLUSION}

The study concluded that blending of custard apple pulp $(35 \%)$ with cow milk (65\%) resulted in most acceptable milk shake and rank between like very much to like extremely.

\section{REFERENCES}

[1] Bakane P.H., Borkar P.A., Gajabe M.H., Khakare M.M.(2015).Physical properties of custard apple fruit (AnnonaSquamosa L.), International Journal of Agricultural Science and Research,Vol .5(4): 343-552.

[2] Bakane P.H., Khakare M.M., Gajabe M.H., Borkar P.A. and Khobragade H.M. (2015).

[3] Chikhalikar N.V., Sahoo A.K., Singhal R.S. and Kulkarni P.R. (2000). Studied on frozen pourable custard apple (AnnonaSquamosa L.) pulp using cryprotectant, Journal of the Science of Food and Agriculture,80(9), 1339-1342.

[4] Comparative storage study of custard apple pulp separated by machine and manual, International journal of agriculture science, Vol.7(8):647-651.

[5] Gopalan C., Rama Shastr B.V. and Balsubramanian S.C.(1991).Nutritive value of Indian Foods, National Institute of Nutrition Haydrabad. pp: 55 and 72.

[6] Gupta, S.A. (1976). Sensory evaluation of food,Indian Dairyman, 28 (8), 293-295.

[7] Indian Horticulture Database (2014).http://nhb.gov.in.

[8] Kadav, V.B. (2001). Preparation of fruit flavoured milk shake,M.Sc. (Ag.)Thesis, Dr. BalashedSawantKonkan Krishi Vidyapeeth, Dapoli, Dist. Ratnagiri (M.S.).

[9] Kashid, U.B. (2005). Preparation of Golden milk shake from cowmilk blended with safflower milk. M.Sc. (Ag.) Thesis, Marathwada Agricultural University, Parbhani.
[10] Kirtikar, K.R. and Basu, S.D. (1955). Indian medicinal plants,Lalit Mohan Basu., Allahabad, India, pp 66-68.

[11] Kotecha P.M., Adsule R.N. and Kadam S.S. (2000). Processing of custard apple: Preparation of ready to serve beverage and wine, India Food Packer,49(5):510.

[12]Mule P.R., Barbind R.P., Korke R.L., Gavit D.P.(2014) Proximate composition, sensory evaluation and production cost of fig milk shake prepared from buffalo milk. Animal Science Reporter, Vol. 8(2).

[13] Panse V.G., Sukhatme P.V. (1976).Statistical methods for agricultural workers, ICAR publication, New Delhi.

[14]Pkalwad S.T., Awaz H.B., Pawar S.L., Poul S.P. (2010). Preparation and sensory evaluation of papaya milk shake, Veterinary world, Vol. 3(4):185-187.

[15] Poul S.P., Sontakke A.T., Munde S.S. and Adangale A.B.(2009).Compostion and economics of custard apple milk shake, The Asian Journal of Animal Science, 4(2):139-142.

[16] Ranganna S. (1986). Handbook of analysis and quality control for fruits and vegetable products, $2 \mathrm{n}$ dedition. Tata McGraw Hill Publishing Co. Ltd. New Delhi.

[17] Rao S.N. (1974).Annona the legendary fruit, Indian Horticulture, 18, 19-20.

[18] Sharma, A.K., Gupta, S .K.(1978). Manufacture of milk shake, Indian Dairyman, 30 (8), 585-586.

[19] Sravanthi T., Waghrey K. and Daddam J.R. (2014). International Journal of Plant, Animal and Environmental Sciences, 4(3), 676-681.

[20] Syed I.H. and Pawar V.N. (2012) Studies on physical and chemical characteristics of custard apple fruit pulp from different locations. J. Dairying, Foods and H.S.,31(2):117-120.

[21] Thimmaiah S.K. (1999). Standard methods of biochemical analysis,Kalyani publication. 